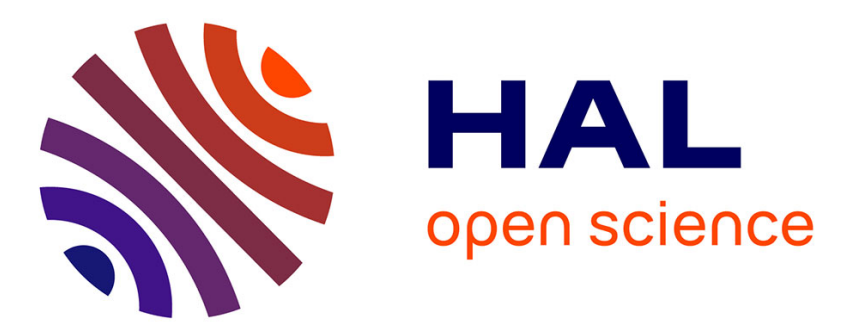

\title{
Perceptions of non-pecuniary job quality using linked employer-employee data
}

Alexander Bryson, Christine Erhel, Zinaida Salibekyan

\section{To cite this version:}

Alexander Bryson, Christine Erhel, Zinaida Salibekyan. Perceptions of non-pecuniary job quality using linked employer-employee data. European Journal of Industrial Relations, 2019, pp.095968011988475. $10.1177 / 0959680119884753$. hal-02965966

\section{HAL Id: hal-02965966 https://hal.science/hal-02965966}

Submitted on 21 Jun 2021

HAL is a multi-disciplinary open access archive for the deposit and dissemination of scientific research documents, whether they are published or not. The documents may come from teaching and research institutions in France or abroad, or from public or private research centers.
L'archive ouverte pluridisciplinaire HAL, est destinée au dépôt et à la diffusion de documents scientifiques de niveau recherche, publiés ou non, émanant des établissements d'enseignement et de recherche français ou étrangers, des laboratoires publics ou privés. 


\title{
Perceptions of Non-Pecuniary Job Quality Using Linked Employer-Employee Data
}

\author{
Alex Bryson, Christine Erhel, Zinaida Salibekyan
}

\begin{abstract}
Using French and British linked employer-employee data this article examines the links between non-pecuniary job quality and workplace characteristics in Britain and France - countries with very different employment regimes. Job quality is measured through eight dimensions which are summarized in a synthetic index. We show that firm size is negatively associated with nonpecuniary job quality in both countries but in France the association is confined to only the largest firms. Internal Labour Markets (ILMs) are associated with higher job quality in France along numerous dimensions. In contrast, ILMs do not improve job quality in Britain except on one dimension - they reduce the adverse effects of work on one's private life.
\end{abstract}

Keywords: non-pecuniary job quality; firm size; internal labour markets; linked employeremployee data 


\section{Introduction}

Job quality affects worker wellbeing (Karasek, 1979; Author A, 2016), worker productivity (Oswald et al., 2015) and thus firm performance (Author A, 2015). It became an EU policy goal at the Lisbon summit in 2000 resulting in the development of a dedicated list of indicators (Laeken indicators) in 2001. It is multi-faceted but its main features are well-known, including dimensions such as wages and income, skills development and training, job security, working hours, job autonomy, job intensity, physical working conditions and social environment (Munoz de Bustillo et al, 2011). It varies markedly across countries, partly reflecting differences in national institutional regimes (Gallie, 2007; Green et al., 2013; Olsen et al, 2010). However, there is also substantial within-country variation in job quality across employees and across workplaces. The latter reflects both structural features of workplaces, such as industry affiliation, and the choices employers make regarding investments in job quality, which in turn reflect perceptions of the costs and benefits of such investments. Osterman (2013), for example, has emphasised the importance of accounting for employer decisions over working conditions when seeking to understand variance in job quality.

In the UK, there has been an increasing focus on job quality. For instance, a recent policy paper by the Carnegie Trust (Irvine et al., 2018) encouraged government to place greater emphasis on job quality rather than focusing solely on the number of jobs created. They defined job quality as multi-faceted, incorporating pay and benefits, health and safety, job design, voice and representation, and work-life balance. In France, the issue of job quality was debated in the last presidential campaign. A publication by a public think-tank linked to the Prime Minister showed France was close to the EU average in terms of job quality, and that job quality (especially the job security dimension) had decreased since the 2008 crisis (France Stratégie, 2016). More recently, the policy debate has focused on the growth in short temporary contracts, and the problems this has caused for workers seeking to maintain unemployment insurance contributions (OFCE, 2018). In July 2019 the government responded with a reform requiring 
employers to make additional insurance contributions for those on contracts of under three months duration.

We contribute to the literature by examining the characteristics of workplaces that are likely to influence workers' perceptions of non-pecuniary job quality in different institutional contexts. By using linked employer-employee data we gain insights into the correlates of job quality that are not available from household surveys. We focus on two workplace features which, we argue, are liable to be important in understanding variance in job quality across workers. These are firm size and the existence of internal labour markets (ILMs), characterized by ongoing skill development, opportunities for career progression and higher returns to seniority. In doing so we exploit similar linked employer-employee data for France and Britain and utilise a multi-dimensional approach to non-pecuniary job quality. Data issues limit our ability to compare identical job quality items across Britain and France. Thus, the aim of the paper is to examine within-country correlations between job quality and workplace characteristics - with a focus on internal labour markets and firm size - taking into account the fact that Britain and France represent very different types of employment regime.

Two hypotheses are tested, based on existing literature. First, job quality should be negatively correlated with firm size, but this effect could be mitigated by regulations in the French case, such as the existence of compulsory worker representation over a certain firm size. The second hypothesis maintains that the existence of an ILM orientation at the workplace level, which means more investment in the stability of the workforce (through wage and promotion policies), should be favorable to job quality. Previous literature has shown that internal labour markets are well-developed in France (Author C, 2016).

As anticipated, the results show that firm size is negatively associated with non-pecuniary job quality in both countries. It is significantly lower in the largest firms (those with 5,000 or more employees) compared with the smallest firms (with fewer than 50 employees). However, whereas in France there is no significant difference in job quality between small and medium sized (50- 
4999 employee) firms, in Britain job quality is significantly lower in the medium-sized compared with the small firms. It is possible that in France the main legal threshold (at 50 employees) (Trésor-Eco, 2016), above which firms are required to respond positively to worker demands for union delegates and work councils, helps mitigate the adverse impact of firm size, at least for medium-sized firms. The results also show that being in a firm with an ILM is associated with better non-pecuniary job quality in France. But this is not the case in Britain.

The article is structured as follows. Section 2 reviews the literature, focusing on the relationship between job quality, firm size and ILMs and outlines our hypotheses. Section 3 describes the linked employer-employee data for the two countries and the empirical methodology. Section 4 presents the results. Section 5 concludes, reflecting on the implications of the analyses while, at the same time, drawing attention to some limitations.

\section{Literature and Hypotheses}

The literature on job quality adopts many different metrics to capture the concept. One strand of academic literature focuses on job satisfaction as a measure of job quality (eg. Clark, 2005). However, most recent academic research on job quality at the European level uses multidimensional definitions of job quality (Gallie 2007, Author B, 2008, Green et al, 2013, Muñoz de Bustillo et al., 2011), incorporating objective indicators (such as working conditions, autonomy, the nature of the employment contract) but also some subjective ones such as perceived job security. Gallie (2007) argues 'objective' and 'job satisfaction' approaches are not necessarily at odds with one another since the components of objective job quality appear correlated with job satisfaction. Despite differences in the dimensions considered by these frameworks, there is agreement about the basic components of job quality: in addition to wages, they usually include working conditions and work autonomy, job security, training and skill development opportunities, as well as work-life balance. 
Factors thought to influence job quality include the sort of employment regime workers face (Gallie, 2007; Author B, 2008). For example, the Varieties of Capitalism (VoC) literature emphasizes the importance of production regimes (Hall and Soskice, 2001). Coordinated Market Economies (CME) like France are characterized by long-term corporate investment and dialogue between employers and unions (often labelled "Social Dialogue" in the European Union), accompanied by substantial vocational training, all of which are conducive to higher levels of job quality. Britain, on the other hand, as a prototypical Liberal Market Economy (LME), is characterized by a financial system imposing short-term horizons on firms and high-risk taking, which is allied to a deregulated labour market and fragmented, uncoordinated employment relations, and an emphasis on general over vocational education, all of which should be conducive to lower job quality.

According to Gallie (2007), job quality also depends on the way employment regimes build power resources for labour and capital. He considers three ideal-types: inclusive, dualist and market regimes. France is a dualist employment regime, with a well-protected core of workers, surrounded by a precarious periphery. Britain exemplifies a market-based employment regime, with very limited regulation and few opportunities for workers to build the sorts of power resources which might be used to generate high quality jobs. However, it may also favour some greater autonomy for workers.

Given these differences in production and employment regimes, perceptions of job quality are likely to differ in Britain and France, and to be influenced by different workplace characteristics. We expect job quality to vary with firm size in both countries. Some effects may lead to a positive relationship between firm size and job quality. Due to their product market dominance, and thus the rents that accrue to them, larger firms may offer their workers higher job quality than might be offered in similar, smaller firms. If so, this may be a form of rentsharing akin to the well-known wage premium linked to firm size (Oi and Idson, 1999). Larger firms also require formal policies and procedures to manage larger groups of employees 
efficiently whereas, in smaller firms, less formal systems may suffice. As such Human Resources departments may devote time and energy to human resource management (HRM) systems which are often equated with job quality, such as the formation of teams, and the conscious design of more attractive jobs offering autonomy and variety.

However, there are also strong theoretical reasons to suspect that job quality deteriorates as firm size increases. Bigger firms are able to use their centralized HR resources to create systems of monitoring and supervision which may be inimical to job quality and may choose to divide up responsibilities and tasks across workers (for instance through Taylorist methods of production, Edwards 1979), which, in smaller firms, may be retained within the same job, thus offering task variety.

Although the theoretical literature regarding firm size and job quality may be ambiguous, the empirical literature on employee perceptions of job quality is unequivocal: employees tend to express greater satisfaction with their jobs in smaller firms (Author A, 2006; Clark and Oswald, 1996). Job satisfaction scholars argue that poor management-employee relationships in large firms are one source of such job dissatisfaction (Tansel and Gazioglu, 2013). Author A (2006) finds that employee job quality in Britain is higher in small firms than in large firms: small firms make less use of shifts, zero hours and annual hours contracts and small firm employees are more likely to say they have high degrees of control and influence in their work when compared with employees in larger firms. The first hypothesis, therefore, is that, in spite of theoretical ambiguities regarding firm size and job quality, firm size will be negatively associated with job quality.

However, there might be some differences in the effect of firm size in France and Britain given the nature of labour market regulations in the two countries and more generally the characteristics of employment regimes. First, in coordinated market economies like France rights to worker representation are dependent on firm size thresholds (Fulton, 2015). Indeed, firms with more than 50 employees have to enable workers to appoint union delegates. It is also 
necessary for them to accede to employee requests for staff delegates where they have more than 10 employees, as well as a works council where they have more than 50 employees. Such regulations are likely to reinforce unions' ability to mobilize core employees in larger firms (Hyman, 2001) and to influence employment conditions. In market employment regimes like Britain organized labour has little involvement in decision-making within firms and its influence is uniform across the economy (Holman, 2013). Besides, because Britain has low levels of employment protection legislation, the standard labour contract is characterized by a high level of flexibility: according to OECD data on employment protection legislation, the UK's employment protections for those on regular contracts is among the lowest in the OECD (1.66 in 2013, compared to an average of 2.38 in the OECD) ${ }^{\mathrm{i}}$. As a result, employers have greater flexibility to hire and fire workers in Britain than in many other European countries, and unions have less power to affect employment conditions (Green, 2013). It seems unlikely, therefore, that union bargaining power would result in firm size differences in job quality in Britain.

Second firm size also matters for training policies in France where firm-funded training aims to provide better opportunities for career development (Paul, 1992). France differs from Britain in placing legal obligations on all firms, but at a higher level for larger firms than for smaller ones ( $1 \%$ of the wage bill for firms with more than 10 employees, $0.55 \%$ for smaller firms). The data used in the current study do not contain workplaces with fewer than 11 employees, so it is not possible to test what effect, if any, this employment threshold has on training-related job quality. Nevertheless, firms' training efforts are directly related with size, even over this 10 employees' threshold, as bigger firms generally spend more than the legal obligation. As a result, training participation rates grow with firm size, from $15.6 \%$ for firms from 10 to 19 employees up to $55.9 \%$ for firms over 2000 employees $^{\mathrm{ii}}$. This is also related to the fact that training is an issue for collective bargaining, at both firm and sector level. British governments also support training policies, but very few collective agreements exist on continuing training, and firms have to invest voluntarily in their workers with little regulation or subsidy (Greenhalgh, 1999; Ok and Tergeist, 
2003). Although employees in larger organisations with 250 or more employees have a right to time off for training after 26 weeks' employment it is a right to unpaid time off. ${ }^{\text {iii }}$ Given these differences in the regulation and functioning of the labour market between the two countries, any negative association between firm size and non-pecuniary job quality is liable to be less pronounced in France than in Britain.

Segmentation theory and the comparative literature emphasise the role played by internal labour markets (ILMs) in determining job quality. As defined by Doeringer and Piore (1971), ILMs imply better career prospects and more developed training to develop and retain core workers, which should be associated with higher job quality. At the country level, segmentation theory suggests the co-existence of a primary sector containing better paying, more stable jobs and a secondary sector, consisting of employees with poor pay, low job security and otherwise unattractive jobs (Piore, 1978). Workplaces with an ILM-type orientation (belonging to the primary sector) may offer better job quality to their employees than workplaces that do not have an ILM orientation.

The segmentation literature characterizes France as a country with strong ILMs where core workers benefit from employment protection, and have better opportunities for career progression within firms, and high returns to seniority (Maurice et al., 1986; Eyraud et al., 1990). On the other hand, peripheral workers in the secondary sector tend to be excluded from firms' investments in training (Marsden, 1990). In contrast to France, Britain used to be considered a country of occupational labour markets (OLM), in which promotions and careers are based on external mobility inside occupations (Eyraudet al., 1990).

Recent literature has shown that these broad differences between the two countries are still valid, although they have weakened. In Britain, firms' use of OLM has diminished since the 1990s, and other forms of mobility have been developing, especially in the service sector: entry into some activities (media, knowledge intensive services) has become very competitive and access to stable and higher status positions largely depends on initial training level and specialty 
(Marsden, 2007). In France, the prevalence of ILMs has declined, especially for cohorts of young entrants (Gautié, 2004), and their functioning has changed: the seniority principle for job progression has diminished in importance, while formal continuous vocational training has become more important for career progression (Béret, Dupray, 1998). However, the general structure of the French labour market remains dual, as indicated by the low transition rates from temporary to permanent work (Le Barbanchon, Malherbet, 2013). Recent empirical research also indicates that ILMs (defined through wage and training practices) still play an important role in French workplaces, whereas they are less frequent in British workplaces (Author C, 2016) ${ }^{\mathrm{iv}}$. Therefore, our second hypothesis is that ILMs play a bigger role in determining job quality in workplaces in France. As ILMs are generally more frequent in bigger firms, this may mitigate the negative firm size effect in the French case.

\section{$3 \quad$ Data and Methods}

The data come from the British Workplace Employment Relations Survey (WERS 2011) and from the French Enquête Relations Professionnelles et Négociations d'Entreprise (REPONSE 2011). The WERS and REPONSE linked employer-employee surveys are among the most authoritative sources of information on employment relations. Other surveys may offer broader coverage of the two economies or a larger set of harmonized data items, but the WERS and REPONSE surveys offer the unique advantage that the samples of workplaces and employees are fully linkable in each country. Detailed information about workplace characteristics (size, location, ownership, union presence, human resource practices) is available permitting analyses of their influence on workers' job quality. The data contain both firm size and workplace size, which are not used interchangeably. They are identical for single-workplace firms.

To harmonise the analysis across France and Britain we selected those private sector workplaces with eleven or more employees and employees with at least 15 months of tenure. The surveys are based on stratified random samples so that when survey weights are applied analyses 
are representative for this population in both countries. The analysis uses equivalently defined samples of 3,947 workplaces and 11,244 employees from REPONSE in 2011 and 1,602 workplaces and 11,581 employees from WERS 2011.

The analysis focuses on non-pecuniary job quality. However, a wage residual ${ }^{v}$ has been introduced in some specifications to capture the pecuniary aspect of job quality and to test for compensating differentials (which imply a negative correlation between wages and non-pecuniary job quality). Eight dimensions of non-pecuniary job quality are investigated, reflecting most of the dimensions defined in the literature: job insecurity, job autonomy, work intensity, training participation, skill development, employee-employer relations, skills matched to job, and adverse effects of work on private life ${ }^{\text {vi }}$. However, caution should be exercised with regard to comparisons between France and Britain because the wording of the questions is different in the two surveys. Differences in wording (see Appendix Tables A1-A4) partly reflect differences in the institutional context where employees are employed (Coutrot, 1998). Thus, this study does not compare directly the levels of non-pecuniary job quality in the two countries.

It is standard in job quality studies to use synthetic indexes to provide an overview of job quality and to take into account the possibility of compensation effects when comparing across jobs (some dimensions may be poor but compensated by a better situation for another dimension). Recent examples of studies using synthetic indexes based on a multiple dimensions of job quality include Green et al. (2013) and Munoz de Bustillo et al. (2011). However, an additive index can hide important differences in job quality across dimensions so it is valuable to decompose the index into its constituent parts and understand what contributes to the observed differences between jobs/workers on sub-indices.

Responses to questions relating to job quality were coded as $0 / 1$ variables where a code " 1 " indicates the job has a particular attribute while a " 0 " indicates it is absent. In a number of cases this entailed recoding ordinal responses into dummy variables. The resulting job quality indicators are presented in Table 1. Full details of the survey questions and weighted distributions are 
presented in Appendix Tables A1-A4, with bivariate correlations between job quality items presented in Appendix Tables A5-A6).

Although the exact question wording is not identical for each item across countries, they are broadly highly comparable - which is not surprising since REPONSE's structure and questionnaires were strongly influenced by the WERS surveys (Amossé et al, 2015). As Appendix Tables A1-A4 indicate, the wording for some items is very similar across country, in others this is less so, but in all cases the comparison passes a face validity check in the sense that the items are clearly capturing the same underlying concept. We therefore undertake statistical analyses to establish whether, in each country, the sub-indices are correlated in a way that indicates they capture a single latent variable which we can call non-pecuniary job quality. We find that they do so. In both countries, factor analyses actually identified a single factor with an eigen value above 1 (2.23 in France and 1.92 in Britain). In France, this factor accounts for 96\% of the variance in the eight items and in Britain it accounts for $89 \%$ of the variance. It is this index we use for each country. The index, which runs from zero to eight, therefore receives statistical support in our data, suggesting we pass a test of construct validity, despite small differences in individual items across countries.

Table 1 shows the percentage of employees in each survey scoring ' 1 ' on each of the job quality items. Relatively few employees in either country perceived their jobs as insecure, even though the surveys took place not long after the Great Recession. In both surveys perceptions of understanding between management and employees are similar, with roughly half giving management positive scores. Question wording in other dimensions makes direct comparisons across countries difficult. For instance, concerning job demand, nearly three-quarters of private sector employees in France (72\%) said they were working under time pressure. when two-fifths $(41 \%)$ of British employees reported that they never had enough time to get the work done. As far as autonomy is concerned, British employees were very likely to say they have some or a lot of influence over how to do their work (85\%). In France, perceived autonomy seems more limited, 
but the question asked is different, since workers are asked if they are free to decide how to work, and $67 \%$ answer positively.

\section{[INSERT TABLE 1]}

Appendix Table A7 presents the distribution of employees across the firm size distribution in each country. ${ }^{\text {vii }}$ Twenty-four per cent of French employees are working in workplaces belonging to firms with between 11 and 49 employees. In Britain, only 15\% are employed in small firms and employees are more concentrated in the largest firms: 31\% are in workplaces which belong to firms with more than 5,000 employees, compared to 16\% in France.

The ILM indicator used in the current study is the one used by Author C (2016) using the same data as the present article. Workplaces with a strong ILM orientation are those which, for a given gender, age, and education profile within the workforce, sit at or above the median in both the distribution of workplace fixed effects for employee job tenure and the distribution of workplace fixed effects on wages. Appendix Table A8 shows that $13 \%$ of employees in Britain are in workplaces with an 'ILM' orientation whereas in France this is the case for 33\% of employees, consistent with the proposition discussed earlier that ILMs are more prevalent in France.

Multivariate models were estimated on the additive job quality indicator having transformed it into a standardized z-score with a mean of zero and standard deviation of 1 , which makes it easier to interpret the quantitative association between job quality and various individual and workplace characteristics. The big advantage of the data that is that workplace and firm traits are not collected from the respondent providing the job quality metrics, but from HR managers. This means we avoid inter-rater biases that plague single respondent surveys such as European Working Conditions Survey, whilst limiting measurement error in dimensions of the workplace such as size - where HR managers' responses are less prone to error than individual employees' responses. 
Ordinary Least Squares models were estimated to capture the variance in job quality across employees in workplaces with different characteristics, based on the following equation

$$
Y_{i j=} \alpha+\beta X_{i j}+\gamma Z_{j}+\lambda I L M_{j}+\mu F_{j}+\varepsilon_{i j}
$$

where $Y_{i j}$ is the dependent variable job quality of employee $I$ in workplace $j$.

$X_{i j}$ corresponds to a vector of demographic and job characteristics namely gender, age (three categories), education (seven categories), union membership, tenure (four categories), type of contract (three categories) and working hours (five categories).

$Z_{j}$ is a vector of workplace and firm characteristics, namely single-digit industry (twelve categories), family ownership (three categories), foreign ownership (two categories), and location (two categories).

ILM is a dummy variable indicating the existence of ILM in the firm $j$, and F represents firm size (four categories).

Estimates are run separately for each country. The empirical analysis includes two steps. In a first step estimations are run to test the relationships between individual and firm characteristics (focusing on firm size and ILM) and job quality, and therefore testing hypotheses1and 2. In a second step the same equation is run with eight different dependent variables $\left(Q_{i j}\right.$ which are $(0,1)$ dummy dependent variables) corresponding to job quality sub-dimensions. 


\section{Results}

Tables 2 and 3 present models for Britain and France respectively testing hypotheses 1 and 2. Before turning to the main results on firm size and ILMs, other results will be briefly discussed that are consistent with our portrayals of France and Britain as different types of employment regime. For example, in France, non-pecuniary job quality is positively correlated with higher levels of education. The finding is consistent with the idea that France has a dualist employment regime in which the more highly educated are able to enter better jobs. In Britain, on the other hand, more highly educated employees report lower job quality, perhaps due to skills mismatch where the expectations of better educated workers do not match the available jobs in the labour market.

In France workplace tenure of less than five years is associated with lower non-pecuniary job quality than being in a workplace ten years or more. This is in line with the expectation that in dualist regimes employees with higher tenure have higher job quality than employees with lower levels of tenure. This does not appear to be the case in Britain, in accordance with expectations regarding a market-oriented employment regime where the "insider" status conferred by high tenure is less relevant.

\section{[INSERT TABLES 2 AND 3]}

Atypical working hours are associated with lower job quality: in France it is part-time workers (30 to 35 hours a week) who suffer lower job quality, while in Britain it is those working long hours (over 41 hours) ${ }^{\text {viii }}$. No association is found with temporary or fixed contracts in France, but this may be explained by the fact that short term contracts are not taken into account here as the REPONSE survey does not include workers who have been employed for less than 15 months. In Britain, those on temporary contracts experience lower job quality. 
Turning to the association between non-pecuniary job quality and workplace features, the focus is on firm size and the presence of ILMs. Concerning firm size, the findings show that working in a large firm (5,000 employees and over) decreases job quality, consistent with hypothesis one. However, the negative association between firm size and job quality is confined to these very large firms in France. In Britain, on the other hand, the negative association is significant and apparent for firms as small as 500 employees. The absence of a firm size effect for medium-sized firms in France may be associated with the worker representation rights accorded workers in firms with at least 50 employees.

The coefficient for ILMs is positive in both countries, but it is only statistically significantly associated with non-pecuniary job quality in France. This confirms our second hypothesis that ILMs play an important role in the French labour market and favour job quality. Furthermore, in the French case the interaction between ILM and the largest firm size (10,000 plus employees) is positive and statistically significant, whereas it is negative and non-significant for Britain (Table A9), thus confirming our contention in hypothesis two that ILMs mitigate the negative association between firm size and job quality, but only in the French case. These results show the relevance of considering ILM practices as important drivers of job quality in the French employment regime, and the need to integrate this feature in workplace-oriented analyses of job quality.

Turning to other features of the employer, industry effects are significant in both countries: compared to manufacturing, energy, construction, health, and business services have significantly higher job quality. Employment in a family-owned business is associated with lower nonpecuniary job quality in France but not in Britain. Forth and Rebérioux (2016) also show the existence of a wage penalty in family-owned firms. Furthermore, the results show that employment in foreign-owned business is associated with lower non-pecuniary job quality in France, but not in Britain. 
In both countries, we have tested models introducing a wage residual to capture the monetary dimension of job quality (table 4 below) and to see how it relates to our non-pecuniary job quality index. As noted earlier the wage residual is obtained from separate log hourly wage regressions for REPONSE and WERS based on OLS models containing gender, age, qualifications and occupation. ${ }^{\text {ix }}$ The results show a positive link between non-pecuniary job quality and wages, which runs counter to expectations regarding compensating wage differential, but rather underlines a strong link between pecuniary and non-pecuniary job quality, as might be the case if workers with strong bargaining power in the labour market, or in workplaces with surplus rents, were able to extract both good wages and good non-wage job quality from their employer. The introduction of the wage residual in the regressions does not change the ILM and firm size effects commented above, therefore confirming the results when the monetary dimension of job quality is taken into account.

\section{[INSERT TABLES 4]}

Several robustness checks have been performed to test for the sensitivity of the results to alternative coding $^{\mathrm{x}}$ or definitions of the variables, as mentioned above (firm size, job quality index): both ILM and firm size effects appear stable.

In a second step, we want to disaggregate the effects of firms' characteristics (and especially firm size and the existence of ILM) on the various components of job quality. The estimates for each of the eight dimensions of job quality are presented in Tables 5 and 6 for France and Britain respectively. The controls are identical to those used in Tables 2 and 3.

\section{[INSERT TABLES 5 AND 6]}

Concerning hypothesis 1 , the negative correlation between firm size and job quality is confirmed for five sub-dimensions in France, the exceptions being job demand, employer- 
employee relations and training participation. Effects for job demand and employer-employee relations are not significant, whereas the link between firm size and training is positive. Negative effects on skill development and work-life balance are concentrated in biggest firms (more than 5000), whereas they also appear for firms of more than 500 employees in the case of job insecurity, skill's match and autonomy.

In Britain, bigger firms are associated with lower job quality in terms of increased job demands, adverse effects on work-life balance, poor employment relations, and lower job autonomy. Firm size matters little for job insecurity, skill development and the job match, and is positive for training, as in the French case.

Concerning hypothesis 2 and the contribution of ILM to perceived job quality, results are quite different in the two countries. In France, working in an ILM workplace is positively associated with 6 of the 8 dimensions of non-pecuniary job quality (skill development, skills match, training participation, job autonomy, work-life balance, and employment relations). In Britain, on the other hand, the only positive association between ILMs and job quality related to work-life balance. This confirms the importance of internal labour markets for workers in France, but not in Britain.

\section{Conclusion}

Using linked employer-employee data we investigated the workplace and firm correlates of non-pecuniary job quality in Britain and France. We focused in particular on the role played by firm size and internal labour markets. Two hypotheses were tested which emanate from the literature on institutional systems in France and Britain. There was broad support for the first hypothesis, which was that firm size would be negatively associated with job quality in both countries. This was the case when estimating a model for job quality using the additive scale, although analyses of subcomponents of job quality revealed quite a complex picture, with firm 
size negatively associated with job quality in nine of the sixteen models, positively associated with job quality in two of the models, and non-significant in the remaining five models.

There was also broad support for the second hypothesis that ILMs improve job quality in France but not in Britain. The result was apparent for the job quality additive scale and was broadly supported when we turned to job quality subcomponents. This result may suggest that specific employment conditions, more favorable to job quality, still exist in France in a segment of the labour market (ILM workplaces). For the two countries, the results show that firms' characteristics and practices matter for job quality, suggesting that job quality policy should take into account firm-level heterogeneity.

Our findings deepen our knowledge of firms' behavior and policy choices in each country. France, as an example of coordinated market economy, tends to create a distinction between core and peripheral employees. It guarantees good non-pecuniary job quality for the core employees who are working in companies with an internal labour market, inducing a risk of strengthening the inequalities between core and peripheral workers. Being in a workplace with an ILM structure in France helps the core employees to have higher skill development perspectives, more possibilities for training participation, better skill's match to a job, higher job autonomy, better relations with the employer and better work-life balance. In Britain, a quintessential liberal market economy, the distinction between core and peripheral workers seems less relevant, and ILMs have less effect on job quality components. In both countries, training participation is higher in bigger firms, which underlines the necessity for training policies to target smaller firms in order in increase that particular job quality component.

There are a number of limitations to this study. It is impossible to tackle the issue of nonrandom exposure of different sorts of workers to different types of job quality environments. Results may differ somewhat once non-random selection is accounted for. Also, it is unclear as to whether poorer perceptions of job quality in large firms reflect objective job quality criteria or whether they simply reflect different reference points of employees in small and large firms. It 
may be, for instance, that those workers who sort into small firms have fundamentally different expectations to those sorting into larger firms, or else they are different sorts of people whose preferences differ in ways that are difficult to observe. Ideally, it is necessary to observe workers switching firms to establish what role unobserved worker heterogeneity plays, but that is not possible with these cross-sectional data. 


\section{Endnotes}

i Data extracted on 25 Jul 2019 09:48 UTC (GMT) from OECD.Stat: https://stats.oecd.org/Index.aspx?DataSetCode=EPL_CD.

iisource : Céreq, Déclarations fiscales des employeurs $n^{\circ} 2483$, http://www.cereq.fr/sousthemes/Enquetes-FC/Le-financement-de-la-formation-par-les-entreprises-24-83.

iii https://www.gov.uk/training-study-work-your-rights

iv According to that analysis, 24.8\% of workplaces are ILMs in France in 2011, against 7.6\% in Britain (Author C, 2016).

vThe wage residual is obtained from separate log hourly wage regressions for REPONSE and WERS based on OLS models containing gender, age, qualifications and occupation. This is intended to capture the wage premium (penalty) a worker receives conditional on his/her human capital attributes.

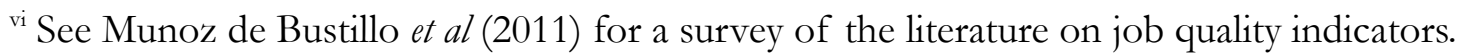

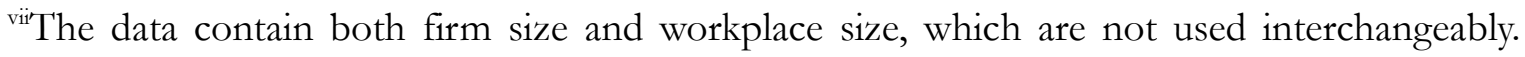
They are identical for single-workplace firms.

viii That result holds when more detailed working time categories are introduced in order to take into account short part-time (which is quite developed in Britain but remains very limited in France).

${ }^{\text {ix }}$ Full details of the derivation of the wage residual are available on request.

${ }^{x}$ We disaggregated the firm size variable to five categories (less than 50; 50-99; 100-999; 1000-4999; 5000 and more). In Britain, job quality is lower in firms with more than 1000 employees, and in France, job quality is lower in large firms with more than 5000 employees. We have also tested the models by adding another category for firm size - more than 10000 employees. In both countries job quality is lower in firms with more than 10000 employees. 


\section{References}

Barbanchon Le T. and Malherbert F. (2013) An anatomy of the French labour market. Country case study on labour market segmentation, International Labour Office, Employment Sector, Employment Working Paper No. 142.

Béret P and Dupray A (1998) La formation professionnelle continue: de l'accumulation de compétences à la validation de la performance, Formation-Emploi, 63, July-September, 6180.

Clark A (2005), Your Money or Your Life: Changing Job Quality in OECD Countries, British Journal of Industrial Relations, 43, pp.377-400.

Clark Aand Oswald A J (1996) Satisfaction and Comparison Income.Journal of Public Economics 61: $359-81$.

Coutrot T (1998) La force de la loi et le royaume du contrat : une comparaison micro-statistique des relations professionnelles en France et en Grande-Bretagne. Travail et Emploi 75: $97-$ 115.

Doeringer P and Piore M (1971) International Labor Market and Manpower Analysis. New York: DC Heath and Company.

Edwards R (1979) Contested Terrain: The Transformation of the Workplace in the $20^{\text {th }}$ Century. New York: Basic Books.

Eyraud F, Marsden D, and Silvestre J (1990) Occupational and internal labour markets in Britain and France. International Labour Review 129(4): 501-17.

Forth J and Rebérioux A (2016) Workplace Structure and Governance: How Do Employer Differ Between Britain and France. In: Amossé T, Bryson A, Forth J, and Petit H (ed.) Comparative Workplace Employment Relations: An Analysis of Practice in Britain and France. Palgrave Macmillan, 27-60.

France Stratégie (2016), "Boosting employment in France", note, http://francestrategie1727.fr/thematiques/politiques-emploi-et-marche-du-travail/ 
Fulton L (2015) Worker representation in Europe. Labour Research Department and ETUI. Available at: http://www.worker-participation.eu/National-Industrial-Relations.

Gallie D (2007) Employment regimes and the quality of work. Oxford University Press, Oxford.

Gautié J (2004) Les marchés internes du travail, l'emploi et les salaires, Revue Française d'Economie, 18, 33-62.

Green F, Mostafa A, Parent-Thirion A, Vermeylen G, Van Houten G, Biletta I,et al. (2013) Is Job Quality Becoming More Unequal?. Industrial and Labour Relations Review 66 (2): 753 794.

Greenhalgh C (1999) Adult Vocational Training and Government Policy in France and Britain. Oxford Review of Economic Policy 15 (1):97-113.

Green F (2013) Is Britain such a bad place to work? The level and dispersion of job quality in comparative European perspective. Centre for Learning and Life Chances in Knowledge Economies and Societies. Available at: http///www.llakes.org.

Hall PA, Soskice D. Varieties of Capitalism: The Institutional Foundations of Comparative Advantage. Oxford University Press; 2001.

Holman D. (2013), Job types and job quality in Europe, Human Relations, 66(4) 475-502

Hyman R (2001) Understanding European Trade Unionism: Between Market, Class and Society. London: Sage.

Irvine G., White, D. and Diffley, M. (2018), Measuring Good Work: The final report of the Measuring Job Quality Working Group (Carnegie UK Trust).

Karasek J R A (1979) Job demands, job decision latitude, and mental strain: Implications for job redesign. Administrative Science Quarterly: 285-308.

Marsden D (1990) Institutions and labour mobility: occupational and internal labour markets in Britain, France, Italy, and West Germany. In Brunetta R and Dell'Aringa (eds.) Labour relations and economic performance (Macmillan, London). 
Marsden D (2007) Labour market segmentation in Britain: the decline of occupational labour markets and the spread of 'entry tournaments Économies et Sociétés, 28. 965-998.

Maurice M, Sellier F and Silvestre J J (1986) The Social Foundations of Industrial Power. Cambridge, Mass.: MIT Press.

Munoz de Bustillo R, Fernández-Macías E, Esteve F,Antón J-I (2011) E pluribus unum? A critical survey of job quality indicators, Socio-Economic Review (9) 3, 1, 447-475

OFCE (2018) Pour une régulation économique des contrats courts sans contraindre les entreprises, en préservant l'Assurance chômage, rapport pour le Sénat, 19 décembre 2018, http://www.senat.fr/fileadmin/Fichiers/Images/delegation/entreprise/Etude_Senat_OF

\section{CE_contratscourts_dec2018.pdf}

Ok W and Tergeist P (2003) Improving Worker's Skills: Analytical Evidence and the Role of the Social Partners.OECD Social, Employment and Migration Working Papers: 10, Paris.

Oi W Y and Idson T L (1999) Firm size and wages. In Ashenfelter O C and Card D (eds.) Handbook of Labor Economics. 3, Part B: 2165-2214.

Olsen K, Kalleberg A, Nesheim T (2010) Perceived job quality in the United States, Great Britain, Norway and West Germany, 1989-2005, European Journal of Industrial Relations, 16 (3): 221-204.

Osterman P (2013) Introduction to the special issue on job quality. Industrial and Labor Relations Review 66 (4): 739-752.

Oswald A J, Proto E. and Sgroi D (2015) Happiness and Productivity. Journal of Labor Economics 33(4): 789-822.

Paul J (1992) Le congé individuel de formation dans les trajectoires professionnelles. Formation Emploi 39: 55-75.

Piore M J (1978) Dualism in the labor market, A response to uncertainty and flux, The case of France. Revue Economique 29: 26-48. 
Tansel A and Gazioglu S (2013) Management Employee Relations, Firm Size and Job Satisfaction. IZA Discussion Paper Series No. 7308.

Thelen K and Kume I (1999) The effects of globalization on labor revisited: lessons from Germany and Japan. Politics and Society 27(4): 477-505.

Trésor-Eco (2016) ‘30 years of modernizing social relations’. January, 160. 
Table 1: Employee Job Quality in the WERS (2011) and REPONSE (2011) surveys.

\begin{tabular}{|c|c|c|c|c|}
\hline & \multicolumn{2}{|l|}{ WERS (Britain) } & \multicolumn{2}{|l|}{ REPONSE (France) } \\
\hline Job insecurity & Feel job is insecure & $16(0.37)$ & Likely to lose job & $16(0.37)$ \\
\hline Job demands & Never enough time & $41(0.49)$ & Time pressure & $72(0.45)$ \\
\hline Job autonomy & Influence over how to work & $85(0.35)$ & Free to decide how to work & $67(0.47)$ \\
\hline $\begin{array}{l}\text { Training } \\
\text { participation }\end{array}$ & $\begin{array}{l}\text { How much organized by } \\
\text { employer }\end{array}$ & $52(0.50)$ & $\begin{array}{l}\text { How much funded by } \\
\text { employer }\end{array}$ & $46(0.50)$ \\
\hline Skill development & Encouraged to develop skills & $56(0.50)$ & Enabled to learn new things & $43(0.50)$ \\
\hline $\begin{array}{l}\text { Employee - } \\
\text { employer relations }\end{array}$ & $\begin{array}{l}\text { Sincere in understanding } \\
\text { employees' views }\end{array}$ & $55(0.50)$ & $\begin{array}{l}\text { Manager pays attention to } \\
\text { what I say }\end{array}$ & $51(0.50)$ \\
\hline $\begin{array}{l}\text { Skills matched to } \\
\text { job }\end{array}$ & $\begin{array}{l}\text { Skills I have match skills } \\
\text { needed }\end{array}$ & $44(0.50)$ & Fully able to use your skills & $63(0.48)$ \\
\hline $\begin{array}{l}\text { Adverse effects of } \\
\text { work on one's } \\
\text { private life }\end{array}$ & $\begin{array}{l}\text { Difficult fulfilling } \\
\text { commitments outside work }\end{array}$ & $29(0.45)$ & $\begin{array}{l}\text { Job allows to organize } \\
\text { private life }\end{array}$ & $36(0.48)$ \\
\hline $\mathrm{N}$ & & 11,581 & & 11,244 \\
\hline $\begin{array}{l}\text { Notes: Table is weight } \\
\text { range from } 0 \text { (low) to }\end{array}$ & . & $\begin{array}{l}\text { quality is } \mathrm{b} \\
\text { eses. }\end{array}$ & on 8-point item scale. The sca & for job quality \\
\hline
\end{tabular}


Table 2: Job Quality (in standardized z-score), in Britain.

\begin{tabular}{|c|c|c|}
\hline Constant & $0.43 * * *$ & $(0.09)$ \\
\hline Gender: male (Ref. female) & -0.04 & $(0.04)$ \\
\hline Age 16-29 (Ref: 31-49) & 0.06 & $(0.04)$ \\
\hline $50+$ & 0.01 & $(0.05)$ \\
\hline Education: Level 2 (Ref: Level 0/1) & $-0.20 * * *$ & $(0.06)$ \\
\hline Level 3 & $-0.19 * * *$ & $(0.05)$ \\
\hline Level5B & $-0.14 * *$ & $(0.07)$ \\
\hline Level $5 \mathrm{~A}$ short & $-0.23 * * *$ & $(0.05)$ \\
\hline Level 5A long & -0.10 & 0.06 \\
\hline Tenure: Less than 5 years (Ref: more than 10 years) & 0.01 & $(0.05)$ \\
\hline 5 to 10 years & -0.01 & $(0.05)$ \\
\hline Hours: 0-29 hours per week (Ref: $36-40$ hours per week) & 0.03 & $(0.04)$ \\
\hline $30-35$ & -0.02 & $(0.05)$ \\
\hline $41-49$ & $-0.15^{* * *}$ & $(0.04)$ \\
\hline $50+$ & $-0.23^{* * *}$ & $(0.06)$ \\
\hline Contract: Temporary (Ref: permanent) & $-0.24 *$ & $(0.14)$ \\
\hline Fixed & 0.03 & $(0.08)$ \\
\hline Union member: yes & $-0.21 * * *$ & $(0.05)$ \\
\hline Firm size: 50-499 (Ref.: less than 50) & -0.04 & $(0.05)$ \\
\hline $500-4999$ & $-0.15^{* *}$ & $(0.06)$ \\
\hline 5000 and more & $-0.15^{* * *}$ & $(0.06)$ \\
\hline ILM workplace: yes (Ref. no) & 0.07 & $(0.06)$ \\
\hline Industry: Energy (Ref: manufacturing) & $0.39 * * *$ & $(0.11)$ \\
\hline Construction & $0.22 * * *$ & $(0.09)$ \\
\hline Wholesale and retail & 0.03 & $(0.08)$ \\
\hline Hotels and restaurants & 0.04 & $(0.09)$ \\
\hline Transport and communication & -0.06 & $(0.10)$ \\
\hline Financial services & 0.18 & $(0.11)$ \\
\hline Other business & $0.16^{* *}$ & $(0.07)$ \\
\hline Education & $0.15^{*}$ & $(0.09)$ \\
\hline Health & $0.32 * * *$ & $(0.08)$ \\
\hline Other community services & 0.07 & $(0.09)$ \\
\hline Family ownership: $25 \%$ of equity capital & -0.05 & $(0.05)$ \\
\hline Foreign ownership: yes (Ref. no) & 0.02 & $(0.06)$ \\
\hline Capital city: yes (Ref.: no) & 0.07 & $(0.06)$ \\
\hline R-squared & \multicolumn{2}{|c|}{0.05} \\
\hline Observations & \multirow{2}{*}{\multicolumn{2}{|c|}{$\begin{array}{c}8,540 \\
962\end{array}$}} \\
\hline Number of workplaces & & \\
\hline
\end{tabular}

Notes: Weighted OLS regressions. Dummies for missing observations are not presented. Clustered standard errors in parentheses. The index of job quality is presented in the section 3 . ${ }^{* * *} \mathrm{p}<0.01 ;{ }^{* *} \mathrm{p}<0.05 ; \mathrm{p}<0.1$.

Base: All employees in the WERS (2011) survey with at least one year's tenure, in private workplaces with 11 or more employees, with no missing data on job quality 
Table 3: Job Quality (in standardized z-score), in France

\section{Constant}

Gender: male (Ref. female)

Age 16-29 (Ref: 31-49)

$50+$

Education: Level 2 (Ref: Level 0/1)

Level 3

Level5B

Level 5A short

Level 5A long

Tenure: Less than 5 years (Ref: more than 10 years)

5 to 10 years

Hours: 0-29 hours per week (Ref: $36-40$ bours per week)

30-35

41-49

$50+$

Contract: Temporary (Ref:permanent)

Fixed

Union member: yes

Firm size: 50-499 (Ref:: less than 50)

500-4999

5000 and more

ILM workplace: yes (Ref. no)

Industry: Energy (Ref: manufacturing)

Construction

Wholesale and retail

Hotels and restaurants

Transport and communication

Financial services

Other business

Education

Health

Other community services

Family ownership: $25 \%$ of equity capital

Foreign ownership: yes (Ref.no)

Capital city: yes (Ref:: no)

$\begin{array}{ll}-0.39 * * * & (0.08) \\ 0.05 & (0.03) \\ 0.04 & (0.04) \\ 0.03 & (0.12)\end{array}$

$0.12 \quad(0.09)$

$0.18^{* * *} \quad(0.05)$

$0.39 * * * \quad(0.06)$

$0.31 * * * \quad(0.07)$

$0.50 * * * \quad(0.07)$

$-0.09 * \quad(0.05)$

$0.004 \quad(0.04)$

$-0.08 \quad(0.06)$

$-0.09 * * \quad(0.04)$

$-0.01 \quad(0.04)$

$-0.08 \quad(0.05)$

$0.16 \quad(0.23)$

$-0.001 \quad(0.08)$

$-0.25 * * * \quad(0.05)$

$-0.06 \quad(0.04)$

$-0.01 \quad(0.05)$

$-0.09 * \quad(0.06)$

$0.22 * * * \quad(0.04)$

$0.47 * * * \quad(0.17)$

$0.25 * * * \quad(0.07)$

$0.07 \quad(0.05)$

$-0.01 \quad(0.14)$

$0.02 \quad(0.06)$

$0.12 \quad(0.09)$

$0.12^{* *} \quad(0.05)$

$-0.08 \quad(0.24)$

$0.28 * * * \quad(0.06)$

$0.21 * * \quad(0.09)$

$-0.16 * * * \quad(0.04)$

$-0.13 * * \quad(0.06)$

$-0.02 \quad(0.04)$

\begin{tabular}{lc}
\hline R-squared & 0.07 \\
\hline Observations & 7,023 \\
Number of workplaces & 2,935 \\
\hline
\end{tabular}

Notes: Weighted OLS regressions. Dummies for missing observations are not presented. Clustered standard errors in parentheses. The index of job quality is presented in the section 3 . ${ }^{* * *} \mathrm{p}<0.01 ; * * \mathrm{p}<0.05 ; \mathrm{p}<0.1$.

Base: All employees in the REPONSE (2011) survey with at least one year's tenure, in private workplaces with 11 or more employees, with no missing data on job quality 
Table 4. Job Quality (in standardized z-score) and Firm size in France and Britain with the wage residual

\begin{tabular}{|c|c|c|c|c|}
\hline \multirow[b]{2}{*}{ Constant } & \multicolumn{2}{|c|}{ France (REPONSE) } & \multicolumn{2}{|c|}{ Britain (WERS) } \\
\hline & $-0.39 * * *$ & $(0.08)$ & $0.45^{* * *}$ & $(0.09)$ \\
\hline Firm size: 50-499 (Ref.: less than 50) & $-0.07 *$ & $(0.04)$ & -0.05 & $(0.05)$ \\
\hline $500-4999$ & -0.02 & $(0.05)$ & $-0.16^{* * *}$ & $(0.06)$ \\
\hline 5000 and more & $-0.10^{*}$ & $(0.06)$ & $-0.17 * * *$ & $(0.06)$ \\
\hline ILM workplace: yes (Ref. no) & $0.17 * * *$ & $(0.04)$ & 0.06 & $(0.06)$ \\
\hline Wage residual & $0.41 * * *$ & $(0.06)$ & $0.11 * * *$ & $(0.03)$ \\
\hline R-squared & \multicolumn{2}{|r|}{0.08} & \multicolumn{2}{|r|}{0.06} \\
\hline Observations & \multicolumn{2}{|c|}{7,020} & \multicolumn{2}{|r|}{7,883} \\
\hline Number of workplaces & \multicolumn{2}{|c|}{2,935} & & 954 \\
\hline
\end{tabular}

Notes: Weighted OLS regressions. Dummies for missing observations are not presented. All models control for individual and workplace job characteristics. Clustered standard errors in parentheses. The index of job quality is presented in the section $3 .{ }^{* * *} \mathrm{p}<0.01 ; * * \mathrm{p}<0.05 ; \mathrm{p}<0.1$.

Base: All employees in the REPONSE (2011) and WERS (2011)surveys with at least one year's tenure, in private workplaces with 11 or more employees, with no missing data on job quality 
Table 5: Subcomponents of job quality in France

\begin{tabular}{|c|c|c|c|c|c|c|c|c|}
\hline & $\begin{array}{l}\text { Job } \\
\text { demand }\end{array}$ & Insecurity & $\begin{array}{l}\text { Skill } \\
\text { development }\end{array}$ & $\begin{array}{l}\text { Skills' match } \\
\text { to a job }\end{array}$ & $\begin{array}{l}\text { Training } \\
\text { participation }\end{array}$ & $\begin{array}{l}\text { Job } \\
\text { autonomy }\end{array}$ & $\begin{array}{l}\text { Adverse } \\
\text { effects of } \\
\text { work on } \\
\text { one's } \\
\text { private life }\end{array}$ & $\begin{array}{l}\text { Employee- } \\
\text { employer } \\
\text { relation }\end{array}$ \\
\hline ILM (Ref.: no) yes & $\begin{array}{l}-0.14 \\
(0.013)\end{array}$ & $\begin{array}{l}-0.02 \\
(0.01)\end{array}$ & $\begin{array}{l}0.08^{* * *} \\
(0.01)\end{array}$ & $\begin{array}{l}0.07^{* * *} \\
(0.02)\end{array}$ & $\begin{array}{l}0.09 * * * \\
(0.01)\end{array}$ & $\begin{array}{l}0.04 * * * \\
(0.01)\end{array}$ & $\begin{array}{l}-0.04^{* * *} \\
(0.01)\end{array}$ & $\begin{array}{l}0.04 * * * \\
(0.02)\end{array}$ \\
\hline Constant & $\begin{array}{l}0.70^{* * *} \\
(0.03)\end{array}$ & $\begin{array}{l}0.19^{* * *} \\
(0.03)\end{array}$ & $\begin{array}{l}0.26^{* * *} \\
(0.03)\end{array}$ & $\begin{array}{l}0.69 * * * \\
(0.03)\end{array}$ & $\begin{array}{l}0.25^{* * *} \\
(0.03)\end{array}$ & $\begin{array}{l}0.61 * * * \\
(0.03)\end{array}$ & $\begin{array}{l}0.30 * * * \\
(0.03)\end{array}$ & $\begin{array}{l}0.44 * * * \\
(0.03)\end{array}$ \\
\hline $\begin{array}{l}\text { R2 } \\
\text { Number of employees } \\
\text { Number of workplaces }\end{array}$ & $\begin{array}{l}0.04 \\
9,465 \\
3,205\end{array}$ & $\begin{array}{l}0.03 \\
7,341 \\
2,977\end{array}$ & $\begin{array}{l}0.09 \\
9,459 \\
3,202\end{array}$ & $\begin{array}{l}0.05 \\
9,443 \\
3,202\end{array}$ & $\begin{array}{l}0.09 \\
9,346 \\
3,189\end{array}$ & $\begin{array}{l}0.07 \\
9,463 \\
3,201\end{array}$ & $\begin{array}{l}0.07 \\
9,464 \\
3,203\end{array}$ & $\begin{array}{l}0.03 \\
9,433 \\
3,198\end{array}$ \\
\hline
\end{tabular}

Notes: Weighted OLS regressions. Dummies for missing observations are not presented. All models control for individual and workplace job characteristics. Clustered standard errors in parentheses. Statistical significance denoted by *** $\mathrm{p}<0.01 ; * * \mathrm{p}<0.05 ; \mathrm{p}<0.1$.

Base: All employees in the REPONSE (2011) survey with at least one year's tenure in private workplaces with 11 or more employees, with no missing data on job quality. 
Table 6: Subcomponents of job quality in Britain

\begin{tabular}{|c|c|c|c|c|c|c|c|c|}
\hline & $\begin{array}{l}\text { Job } \\
\text { demand }\end{array}$ & Insecurity & $\begin{array}{l}\text { Skill } \\
\text { development }\end{array}$ & $\begin{array}{l}\text { Skills' match } \\
\text { to a job }\end{array}$ & $\begin{array}{l}\text { Training } \\
\text { participation }\end{array}$ & $\begin{array}{l}\text { Job } \\
\text { autonomy }\end{array}$ & $\begin{array}{l}\text { Adverse } \\
\text { effects of } \\
\text { work on } \\
\text { one's } \\
\text { private life }\end{array}$ & $\begin{array}{l}\text { Employee- } \\
\text { employer } \\
\text { relation }\end{array}$ \\
\hline $\begin{array}{l}\text { Firm size:50-499 } \\
\text { (Ref.: less than 50) } \\
\text { 500-4,999 } \\
\text { 5,000 and more }\end{array}$ & $\begin{array}{l}0.02 \\
(0.02) \\
0.05^{*} \\
(0.03) \\
0.06^{* *} \\
(0.03) \\
\end{array}$ & $\begin{array}{l}0.01 \\
(0.02) \\
0.04^{*} \\
(0.02) \\
0.03 \\
(0.02) \\
\end{array}$ & $\begin{array}{l}0.002 \\
(0.03) \\
-0.03 \\
(0.03) \\
0.01 \\
(0.03)\end{array}$ & $\begin{array}{l}-0.03 \\
(0.02) \\
-0.05^{* *} \\
(0.02) \\
-0.03 \\
(0.02)\end{array}$ & $\begin{array}{l}0.05 \\
(0.03) \\
0.10 * * * \\
(0.03) \\
0.06 * * \\
(0.03)\end{array}$ & $\begin{array}{l}-0.02 \\
(0.01) \\
-0.05^{* * *} \\
(0.01) \\
-0.06^{* * *} \\
(0.02)\end{array}$ & $\begin{array}{l}0.01 \\
(0.02) \\
0.04 * * \\
(0.02) \\
0.06 * * * \\
(0.02)\end{array}$ & $\begin{array}{l}-0.05^{* *} \\
(0.03) \\
-0.09^{* * *} \\
(0.03) \\
-0.08^{* * *} \\
(0.03)\end{array}$ \\
\hline ILM (Ref.: no) yes & $\begin{array}{l}0.02 \\
(0.03)\end{array}$ & $\begin{array}{l}-0.01 \\
(0.02)\end{array}$ & $\begin{array}{l}0.01 \\
(0.03)\end{array}$ & $\begin{array}{l}0.02 \\
(0.02)\end{array}$ & $\begin{array}{l}0.04 \\
(0.03)\end{array}$ & $\begin{array}{l}0.02 \\
(0.02)\end{array}$ & $\begin{array}{l}-0.03^{*} \\
(0.02)\end{array}$ & $\begin{array}{l}0.02 \\
(0.03)\end{array}$ \\
\hline Constant & $\begin{array}{l}0.31 * * * \\
(0.04)\end{array}$ & $\begin{array}{l}0.10^{* * *} \\
(0.04)\end{array}$ & $\begin{array}{l}0.64^{* * *} \\
(0.05)\end{array}$ & $\begin{array}{l}0.68^{* * *} \\
(0.04)\end{array}$ & $\begin{array}{l}0.26 * * * \\
(0.05)\end{array}$ & $\begin{array}{l}0.94 * * * \\
(0.03)\end{array}$ & $\begin{array}{l}0.09 * * * \\
(0.03)\end{array}$ & $\begin{array}{l}0.64 * * * \\
(0.04)\end{array}$ \\
\hline $\begin{array}{l}\text { R2 } \\
\text { Number of employees } \\
\text { Number of workplaces }\end{array}$ & $\begin{array}{l}0.07 \\
9,047 \\
964\end{array}$ & $\begin{array}{l}0.05 \\
8,908 \\
965\end{array}$ & $\begin{array}{l}0.04 \\
9,079 \\
965\end{array}$ & $\begin{array}{l}0.03 \\
9,154 \\
965\end{array}$ & $\begin{array}{l}0.10 \\
9,137 \\
965\end{array}$ & $\begin{array}{l}0.04 \\
9,115 \\
965\end{array}$ & $\begin{array}{l}0.11 \\
9,161 \\
965\end{array}$ & $\begin{array}{l}0.05 \\
9,081 \\
965\end{array}$ \\
\hline
\end{tabular}

Notes: Weighted OLS regressions. Dummies for missing observations are not presented. All models control for individual and workplace job characteristics. Standard errors in parentheses. Statistical significance denoted by $* * * \mathrm{p}<0.01 ; * * \mathrm{p}<0.05 ; \mathrm{p}<0.1$.

Base: All employees in the WERS (2011) survey with at least one year's tenure in private workplaces with 11 or more employees, with no missing data on job quality. 


\section{Appendices}

A1. Job Quality variables in the WERS survey

\begin{tabular}{|c|c|c|c|c|c|}
\hline & $\begin{array}{l}\text { Strongly } \\
\text { agree }\end{array}$ & Agree & $\begin{array}{l}\text { Neither } \\
\text { agree nor } \\
\text { disagree }\end{array}$ & Disagree & $\begin{array}{l}\text { Strongly } \\
\text { disagree }\end{array}$ \\
\hline & \multicolumn{2}{|c|}{ Coded 1} & \multicolumn{3}{|c|}{ Coded 0} \\
\hline $\begin{array}{l}\text { Job demand } \\
\text { I never seem to have enough time to get my } \\
\text { work done }(\mathrm{N}=11,333)\end{array}$ & 14 & 27 & 31 & 25 & 3 \\
\hline $\begin{array}{l}\text { Job insecurity } \\
\text { I feel my job is secure in this workplace } \\
(\mathrm{N}=11,147)\end{array}$ & 17 & 46 & 21 & 12 & 5 \\
\hline $\begin{array}{l}\text { Employee-employer relations } \\
\text { Managers are sincere in attempting to } \\
\text { understand employees' views }(\mathrm{N}=11,370)\end{array}$ & 11 & 43 & 24 & 15 & 6 \\
\hline $\begin{array}{l}\text { Skill development } \\
\text { Managers encourage to develop their skills } \\
(\mathrm{N}=11,351)\end{array}$ & 13 & 42 & 26 & 13 & 6 \\
\hline \multirow[t]{3}{*}{$\begin{array}{l}\text { Adverse effects of work on one's private } \\
\text { life } \\
\text { I often find it difficult to fulfill my } \\
\text { commitments outside of work because of the } \\
\text { amount of time I spend on my job } \\
(\mathrm{N}=11,506)\end{array}$} & 9 & 20 & 25 & 37 & 9 \\
\hline & $\begin{array}{l}\text { Strongly } \\
\text { agree }\end{array}$ & Agree & $\begin{array}{l}\text { Neither } \\
\text { agree nor } \\
\text { disagree }\end{array}$ & Disagree & $\begin{array}{l}\text { Strongly } \\
\text { disagree }\end{array}$ \\
\hline & \multicolumn{3}{|c|}{ Coded 0} & \multicolumn{2}{|c|}{ Coded 1} \\
\hline $\begin{array}{l}\text { Job insecurity } \\
\text { I feel my job is secure in this workplace } \\
(\mathrm{N}=11,147)\end{array}$ & 17 & 46 & 21 & 12 & 4 \\
\hline $\begin{array}{l}\text { Notes: Weighted frequencies in cells in } \\
\text { strongly agreed that they never seemed to have } \\
\text { Base: All employees with at least one ye } \\
\text { more employees, with no missing data on job }\end{array}$ & $\begin{array}{l}\text { percenta } \\
\text { enough } \\
\text { ar of ten } \\
\text { uality. }\end{array}$ & $\begin{array}{l}\text { s. } 14 \% \\
\text { e to get } \\
\text { e, in priv }\end{array}$ & $\begin{array}{l}\text { ff employee } \\
\text { heir work dol } \\
\text { ate sector w }\end{array}$ & $\begin{array}{l}\text { S reported } \\
\text { he. } \\
\text { orkplaces }\end{array}$ & $\begin{array}{l}\text { that they } \\
\text { vith } 11 \text { or }\end{array}$ \\
\hline
\end{tabular}


Training participation: Apart from health and safety training, how much training have you had during the last 12 months, either paid or organized by your employer?

None

34

Less than 1 day

13

1 to less than 2 days

16

2 to less than 5 days

20

5 to less than 10 days

10

10 days and more

6

0

$\mathrm{N}=11,468$

Skills' match to a job: How well do the work skills you personally have match the skills you need to do your present job?

Much higher

A bit higher

20

0

About the same

32

44

A bit lower

4

Much lower

1

0

$\mathrm{N}=11,489$

Job autonomy: In general, how much influence do you have over how to do your work?

A lot

54

Some

31

A little

10

None

5

$\mathrm{N}=11,446$

Notes: frequencies in cells in percentages. $34 \%$ of employees reported that they had no training in the last 12 months, $20 \%$ of employees reported that their skills are much higher than the present job they had, and $54 \%$ of employees reported that they had a lot of influence over their work.

Source: WERS (2011) survey. 
A3. Job Quality variables in the REPONSE survey

\begin{tabular}{|c|c|c|c|c|}
\hline & Always & Often & Sometimes & Never \\
\hline & \multicolumn{2}{|c|}{ Coded 1} & \multicolumn{2}{|c|}{ Coded 0} \\
\hline $\begin{array}{l}\text { Job demand: In your work, is there } \\
\text { any time pressure? }(\mathrm{N}=11,160)\end{array}$ & 31 & 41 & 25 & 2 \\
\hline $\begin{array}{l}\text { Adverse effects of work on one's } \\
\text { private life } \\
\text { Does your work allow you to organize } \\
\text { your private life satisfactorily? } \\
(\mathrm{N}=11,179)\end{array}$ & 18 & 45 & 30 & 6 \\
\hline $\begin{array}{l}\text { Job autonomy: Are you free to decide } \\
\text { how to do your work? }(\mathrm{N}=11,161)\end{array}$ & 20 & 47 & 23 & 10 \\
\hline $\begin{array}{l}\text { Skills' match to a job: In your work, } \\
\text { are you fully able to use your skills? } \\
\mathrm{N}=11,132\end{array}$ & 19 & 45 & 30 & 7 \\
\hline $\begin{array}{l}\text { Skill development: Does your work } \\
\text { enable you to learn new things? } \\
\mathrm{N}=11,147\end{array}$ & 11 & 32 & 45 & 12 \\
\hline $\begin{array}{l}\text { Employee-employer relations: Does } \\
\text { your line manager pay attention to } \\
\text { what you say? }(\mathrm{N}=11,115)\end{array}$ & 15 & 36 & 39 & 10 \\
\hline \multicolumn{5}{|c|}{$\begin{array}{l}\text { Notes: Weighted frequencies in cells in percentages. } 18 \% \text { of employees reported } \\
\text { that work always allowed them to organize private life satisfactorily. }\end{array}$} \\
\hline $\begin{array}{l}\text { Base: All employees with at least or } \\
\text { with } 11 \text { or more employees, with no mi }\end{array}$ & $\begin{array}{l}\text { le year of } \\
\text { sing data }\end{array}$ & nure, in 1 & $\begin{array}{l}\text { rivate sector } \mathrm{v} \\
\text { ty. }\end{array}$ & orkplaces \\
\hline
\end{tabular}

A4. Other job quality variables in the REPONSE survey

\section{Weighted Frequencies Coded}

Training participation: During the last three years, have you undertaken any vocational training financed by your employer? (REPONSE survey)

$\begin{array}{lll}\text { Yes } & 46 & 1 \\ \mathrm{No} & 54 & 0 \\ \mathrm{~N}=11,002 & \end{array}$

Job insecurity: During the next 12 months, what is the likelihood of losing the job?

Very high

High

Low

Nil

$\mathrm{N}=8,593$
5

11

47

37

Notes: frequencies in cells in percentages. $46 \%$ of employees reported that they had vocational training in the past three years, $5 \%$ of employees reported that the likelihood was very high to lose the job.

Base: All employees with at least one year of tenure, in private sector workplaces with 11 or more employees, with no missing data on job quality.

Source: REPONSE (2011) survey. 
A5: Correlation matrix of job quality measures in the REPONSE survey

1. Free to decide how to work

\begin{tabular}{lrrrrrrr}
\multicolumn{1}{c}{1} & 2 & 3 & 4 & 5 & 6 & 7 & 8 \\
\hline 1.00 & & & & & & & \\
-0.16 & 1.00 & & & & & & \\
-0.20 & 0.13 & 1.00 & & & & & \\
0.26 & -0.12 & -0.11 & 1.00 & & & & \\
0.34 & -0.19 & -0.15 & 0.39 & 1.00 & & & \\
0.11 & -0.09 & -0.03 & 0.19 & 0.13 & 1.00 & & \\
0.31 & -0.20 & -0.21 & 0.29 & 0.34 & 0.13 & 1.00 & \\
& & & & & & & \\
-0.06 & 0.05 & 0.15 & 0.03 & -0.03 & 0.03 & -0.06 & 1.00 \\
\hline
\end{tabular}

2. Believes job is not secure

3. Work adversely affects private life

4. Able to learn or develop skills

5. Skills matched to job

th 11 or more employees with at least one year's tenure in private sector

6. Training received

7. Manager pays attention/understands employees

8. Working under time pressures Base: Employees of
workplace. $\mathrm{N}=8,201$

A6: Correlation matrix of job quality measures in the WERS survey

1. Free to decide how to work

2. Believes job is not secure

\begin{tabular}{lrrrrrrr}
\multicolumn{1}{c}{1} & 2 & 3 & 4 & 5 & 6 & 7 & 8 \\
\hline 1.00 & & & & & & & \\
-0.13 & 1.00 & & & & & & \\
-0.05 & 0.09 & 1.00 & & & & & \\
0.19 & -0.19 & -0.11 & 1.00 & & & & \\
0.05 & -0.08 & -0.06 & 0.13 & 1.00 & & & \\
0.09 & -0.08 & 0.02 & 0.26 & 0.03 & 1.00 & & \\
0.19 & -0.22 & -0.13 & 0.51 & 0.09 & 0.14 & 1.00 & \\
& & & & & & & \\
-0.01 & 0.07 & 0.27 & -0.04 & -0.02 & 0.04 & -0.08 & 1.00
\end{tabular}

3. Work adversely affects private life

4. Able to learn or develop skills

5. Skills matched to job

6. Training received

Base: Employees of all firms with 11 or more employees with at least one year's tenure in private sector workplace. $\mathrm{N}=10,592$ 
A7: The distribution of employees across firm size in the WERS and REPONSE surveys.

\begin{tabular}{cc|c}
\hline & Britain (WERS) & France (REPONSE) \\
\hline $11-49$ & $15 \%$ & $24 \%$ \\
$50-499$ & $23 \%$ & $34 \%$ \\
$500-4,999$ & $29 \%$ & $25 \%$ \\
5,000 and more & $31 \%$ & $16 \%$ \\
Missing & $2 \%$ & $1 \%$ \\
\hline $\mathrm{N}$ & 11,581 & 11,244 \\
\hline
\end{tabular}

Notes: Weighted frequencies in cells in percentages.

Base: All employees with at least one year of tenure, in private sector workplaces with 11 or more employees,

A8: The share of employees in workplaces with an ILM orientation in the WERS and REPONSE surveys

\begin{tabular}{cc|c}
\hline & Britain (WERS) & France (REPONSE) \\
\hline Yes & $13 \%$ & $33 \%$ \\
No & $80 \%$ & $65 \%$ \\
Missing & $7 \%$ & $2 \%$ \\
\hline $\mathrm{N}$ & 11,581 & 11,244
\end{tabular}

Notes: In the WERS survey $13 \%$ of employees are in workplaces which have an 'ILM' orientation in the WERS survey. The ILM orientation of the workplace is defined by Forth et al. (2016) as the share of workplaces with high levels of job tenure and the payment of above market wages.

Base: All employees with at least one year of tenure, in private sector workplaces with 11 or more employees 


\section{Constant}

Firm size: 100-999 (ref.: <100)

$5000-9999$

10,000 and more

ILM workplace : Yes (ref.: no)

Firm size $(<100) *$ ILM (ref. no) 100-999*ILM (yes)

1000-4999*ILM (yes)

5000 - 9999* ILM (yes)

10,000 and more * ILM (yes)
Britain (WERS) $\quad$ France (REPONSE)

$0.39 * * *$

$(0.08)$

0.034

$(0.05)$

$-0.134 *$

$(0.077)$

$-0.083$

$(0.108)$

$-0.113^{*}$

$(0.058)$

0.128

(0.119)

$-0.007$

$(0.16)$

$-0.18$

$(0.18)$

0.02

$(0.19)$

$-0.20$

$(0.15)$

R-squared

0,06

Observations

8,540

962

Number of workplaces

Notes: Weighted OLS regres individual and workplace job characteristics. Clustered standard errors in parentheses. The index of job quality is presented in the section 3. ${ }^{* * *} \mathrm{p}<0.01 ;{ }^{* *} \mathrm{p}<0.05 ; \mathrm{p}<0.1$

Base: All employees in the REPONSE (2011) and WERS (2011)surveys with at least one year's tenure, in private workplaces with 11 or more employees, with no missing data on job quality

$-0.44 * * *$

0.042

$(0.05)$

0.047

$(0.06)$

0.037

(0.14)

$-0.157 * *$

$(0.06)$

$0.182^{* * *}$

(0.062)

$-0.003$

(0.08)

0.04

$(0.09)$

0.03

(0.23)

$0.23 * *$

(0.12)

0,07

7,023

2,935

3

